\title{
Secretion of a mucous cord for drifting by the clam Meretrix Iusoria (Veneridae)
}

\author{
YASUO NAKAMURA* \\ National Institute for Environmental Studies, Tsukuba, Ibaraki 305-8506, Japan
}

Received 28 July 2012; Accepted 24 January 2013

\begin{abstract}
The bivalve Meretrix lusoria secretes a mucous cord and drifts on tidal flats using the cord as a "sail." To explain the drifting patterns of the clams in the field obtained in previous studies, conditions affecting cord secretion were examined in the laboratory. The results are summarized as follows: 1) clams over a wide size range (11-45 mm in shell length) secreted cords over a wide range of temperatures $\left(10-30^{\circ} \mathrm{C}\right)$ with stimulation by air bubbling of the water and 2) cord-secretion activity depended on the season of collection, with maximum activity in spring and minimum in summer. In general, these results explained well the drifting patterns of the clams observed previously in the field.
\end{abstract}

Key words: bivalves, drift, Meretrix lusoria, mucous cord secretion, tidal flats

\section{Introduction}

Some bivalve species drift in the water column and expand their distribution during post-metamorphic stages (see, for example, Bayne 1964, Prezant \& Chalermwat 1984, Beukema \& Vlas 1989, Hiddink \& Wolff 2002). In most cases, such drifts are facilitated by a long byssus thread secreted from the foot, which acts like a sail by increasing hydrodynamic drag (Sigurdsson et al. 1976, Lane et al. 1985, Sorlin 1988, Beukema \& Vlas 1989). In another case, the clam Corbicula fluminea (Muller 1774) secretes a transparent mucous cord from its exhalent siphon and uses this as a sail for drifting (Prezant \& Chalermwat 1984). A suggested ecological role of such drifting is to escape from unfavorable environments (Beukema \& Vlas 1989, Hiddink \& Wolff 2002).

The present study focuses on the venerid clam Meretrix lusoria (Roeding 1798), which lives in sandy sediments of shallow coastal waters off Japan and the southern Korean Peninsula (Trii et al. 2010). This clam used to be an important fishery resource in Japanes estuaries, but the catch of $M$. lusoria in Japan has decreased drastically since the 1970s (Higano 2004). Meretrix lusoria secretes a transparent mucous cord from tissue near the siphons (Fig. 1; Kishinouye 1913). Its viscosity declines within a day of secretion and is composed of a polysaccharide with a molec-

\footnotetext{
*Corresponding author: Y. Nakamura; E-mail, yasuo@nies.go.jp
}

ular weight greater than $3000 \mathrm{Da}$ (Nakamura unpublished data). Uchida (1941) observed Meretrix meretrix (Linnaeues) [probably Meretrix lusoria according to Trii et al. (2010)], of shell length $3-5 \mathrm{~cm}$, trailing a cord (length $2-5 \mathrm{~m}$ ), drifting with the tidal current on a tidal flat off the southern Korean Peninsula. He also placed rectangularmouthed "clam traps" $(60 \mathrm{~cm}$ wide $\times 30 \mathrm{~cm}$ high) with collecting nets at $0-150 \mathrm{~cm}$ above the surface of a tidal flat off the northwestern Korean Peninsula and found that M. meretrix [probably M. petechialis (Trii et al. 2010)] drift mainly in the layer close to the sediment (within $30 \mathrm{~cm}$ ), on ebbing spring tides during summer and early fall. On the basis of histological analysis, Hamada \& Ino (1954) suggested that the mucous cord of M. lusoria is secreted from tissue in the inner wall of the mantle surrounding the siphons.

Following these earlier reports, the only follow-up on the mucous cord of Meretrix spp. is that by Takahi \& Henmi (2011), who performed monthly counts of the number of $M$. lusoria clams stranded on obstacles on a tidal flat (cobbles flanking the road) as an index of drift. They suggested that drifting of M. lusoria in Kyushu, Japan, occurs mainly from January to July.

There are few empirical studies focusing on the factors affecting the secretion of mucous materials used for drifting (Sorlin 1988, Martel \& Diefenbach 1993). The present study involved laboratory experiments designed to clarify the conditions favorable for mucous cord secretion by $M$. 

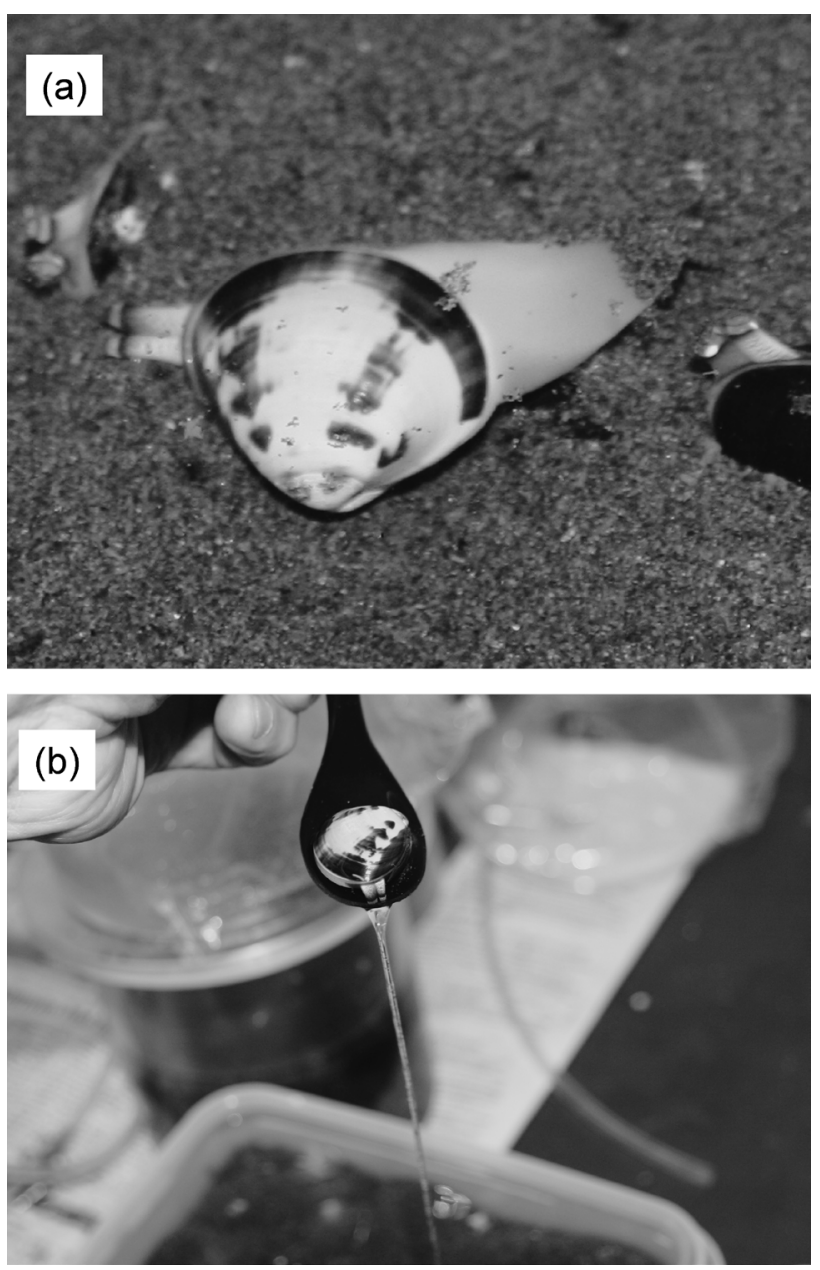

Fig. 1. (a) Meretrix lusoria in the position for secreting a mucous cord (see also Results section on Experiment 6; Table 1), and (b) the mucous cord secreted. Both photographs were taken during Experiment 6.

lusoria, with the aim of providing insights into drifting patterns of the clams in the field and the ecological roles of cord secretion.

\section{Materials and Methods}

\section{Materials and sampling sites}

Meretrix lusoria clams from the natural population on the sandy Shirakawa tidal flat (Kyushu, Japan; $32^{\circ} 47^{\prime} \mathrm{N}$, $130^{\circ} 36^{\prime} \mathrm{E}$; area of the flat $=4.2 \mathrm{~km}^{2}$; Tamaki et al. 2008), or clams introduced from Shirakawa flat to cages on Oi tidal flat (Tokyo Bay, Japan; $35^{\circ} 35^{\prime} \mathrm{N}, 139^{\circ} 45^{\prime} \mathrm{E}$; area of the flat $=0.02 \mathrm{~km}^{2}$; Nakamura et al. 2010) were used throughout this study (Table 1). On Shirakawa flat, M. lusoria is distributed mainly between the shoreline and mean low water neap tide (MLWN) at densities from $<3$ to 100 ind. $\mathrm{m}^{-2}$ for clams with a shell length $>10 \mathrm{~mm}$ (Tamaki \& Takahara unpublished data). Although there was no natural population of M. lusoria on Oi flat, the clams caged there grew rapidly with high survival, and their reproductive cycle followed the same pattern as on Shirakawa flat (Nakamura et al. 2010). The seasonal change of water temperature over both flats follows almost the same pattern: maximum $\left(30^{\circ} \mathrm{C}\right)$ in August and minimum $\left(12^{\circ} \mathrm{C}\right)$ in February (Nakamura et al. 2010). The salinities on the Shirakawa and Oi flats were generally $25-30$ and $15-25$, respectively (Nakamura et al. 2010). In experiments where the same clams were used repeatedly for several months (Experiment 5; Table 1), caged clams on Oi flat were used. Caged clams were also used for experiments conducted in mid-winter, when it was difficult to collect a sufficient number of clams from Shirakawa flat.

Kuroshio seawater filtered through glass fiber filters (Whatman GF/C) and diluted to a salinity of 25 was used throughout this study.

\section{Experimental protocol for testing for mucous cord se- cretion}

Clams from the sampling sites were collected during the spring tide period, placed in a plastic container $(4 \mathrm{~L})$, cooled to $10-15^{\circ} \mathrm{C}$, and brought to the laboratory within $24 \mathrm{~h}$. Seawater was not added to the container to prevent clams from cord secretion. The clams were then placed in 4-L plastic containers containing $1 \mathrm{~L}$ oxygen-saturated seawater (salinity=25) and sand (depth $3 \mathrm{~cm}$ ). After $30 \mathrm{~min}$, when most of the clams had burrowed into the sand, the seawater was continuously bubbled with air through an air-stone, and the clams were maintained in a temperature-controlled room $\left(20^{\circ} \mathrm{C}\right)$ for $2-6 \mathrm{~d}$ without added food. During this period, sand-burrowing clams rarely secreted a mucous cord under air bubbling. However, ones that had secreted a cord were removed and not used in the following experiments.

On the day of secretion experiments, clams were retrieved from the containers and each individual clam was placed into a $200-\mathrm{mL}$ beaker containing $150 \mathrm{~mL}$ oxygensaturated filtered seawater at $20^{\circ} \mathrm{C}$ (time $=0 \mathrm{~h}$ ). The clams were lifted using a plastic spoon and checked for the secretion of a cord $0.8 \mathrm{~h}$ after being placed in the beaker (Fig. 1b). If the clam had not secreted a cord, it was returned to the beaker, and at $1 \mathrm{~h}$ the seawater was aerated by bubbling air through an air-stone $(20 \mathrm{~mm}$ in diameter) for $2 \mathrm{~min}$. Care was taken that the clam did not touch the air-stone or bubbles. The clam was then checked again for cord secretion as described above. If the clam had not secreted a cord, 2-min bubbling was repeated at $2 \mathrm{~h}$ and $3 \mathrm{~h}$. The cumulative proportion of clams that secreted the cord at time $t(f, \%)$ was calculated as

$$
f=(X / N) \times 100,
$$

where $X$ is the total number of clams that had secreted a cord at or before time $t$, and $N$ is the total number of clams. The $f$-value at the end of experiment $(t=3 \mathrm{~h})$ was denoted 
Table 1. Summary of mucous cord secretion experiments with Meretrix lusoria.

\begin{tabular}{|c|c|c|c|c|c|c|c|}
\hline Experimental treatment & $\begin{array}{c}\text { Name of } \\
\text { experiment }\end{array}$ & Trial & $\begin{array}{l}\text { Number of } \\
\text { clams used }\end{array}$ & $\begin{array}{l}\text { Shell length } \\
\quad(\mathrm{mm})\end{array}$ & $\begin{array}{l}\text { Sampling } \\
\text { location }\end{array}$ & Sampling period & $\begin{array}{l}\text { Period of trans- } \\
\text { plant to Oi flat }\end{array}$ \\
\hline Air bubbling (water movement) & Exp 1 & & 72 & $14-20$ & Shirakawa & November 8, 2011 & \\
\hline Exposure to air & Exp 2 & $\begin{array}{l}1 \\
2\end{array}$ & $\begin{array}{l}70 \\
66\end{array}$ & $\begin{array}{l}14-20 \\
13-21\end{array}$ & $\begin{array}{l}\text { Shirakawa } \\
\text { Shirakawa }\end{array}$ & $\begin{array}{l}\text { November 8, } 2011 \\
\text { February 20, } 2011\end{array}$ & \\
\hline Shell length & Exp 3 & $\begin{array}{l}1 \\
2\end{array}$ & $\begin{array}{l}48 \\
78\end{array}$ & $\begin{array}{l}13-33 \\
11-33\end{array}$ & $\begin{array}{l}\text { Shirakawa } \\
\text { Shirakawa }\end{array}$ & $\begin{array}{l}\text { November 22, } 2010 \\
\quad \text { March 5, } 2012\end{array}$ & \\
\hline Temperature & Exp 4 & $\begin{array}{l}1 \\
2\end{array}$ & $\begin{array}{r}109 \\
90\end{array}$ & $\begin{array}{l}16-22 \\
15-20\end{array}$ & $\begin{array}{c}\text { Oi } \\
\text { Shirakawa }\end{array}$ & $\begin{array}{c}\text { February 9, } 2012 \\
\text { February 20, } 2012\end{array}$ & November 2011 \\
\hline \multirow{4}{*}{ Seasonal variations } & \multirow{4}{*}{ Exp 5} & 1 & 12 & \multirow{4}{*}{$\begin{array}{l}23-32 \text { (start) } \\
31-47 \text { (end) } \\
23-35 \text { (start) } \\
32-48 \text { (end) } \\
12-22 \text { (start) } \\
19-30 \text { (end) } \\
13-22 \text { (start) } \\
24-33 \text { (end) }\end{array}$} & Oi & \multirow{4}{*}{$\begin{array}{l}\text { March-December } 2010 \\
\text { once in } 1-2 \text { months } \\
\text { April-December } 2010 \\
\text { once in 1-2 months } \\
\text { June-November } 2010 \\
\text { once in 1-2 months } \\
\text { March-July } 2011 \\
\text { once in a month }\end{array}$} & May 2009 \\
\hline & & 2 & 12 & & Oi & & May 2009 \\
\hline & & 3 & 32 & & Oi & & June 2010 \\
\hline & & 4 & $58^{\mathrm{a}}$ & & Oi & & November 2010 \\
\hline $\begin{array}{l}\text { Cord secretion by sand- } \\
\text { burrowing clams }\end{array}$ & Exp 6 & $\begin{array}{l}1 \\
2\end{array}$ & $\begin{array}{l}80 \\
86\end{array}$ & $\begin{array}{r}20-30 \\
8-16\end{array}$ & $\begin{array}{l}\text { Shirakawa } \\
\text { Shirakawa }\end{array}$ & $\begin{array}{c}\text { May } 2011 \\
\text { August } 2011\end{array}$ & \\
\hline
\end{tabular}

${ }^{a}$ For the experiment each month, 11-12 clams were used.

as $f_{\mathrm{E}}$, and was used as an index for the degree of cord secretion under a given set of experimental conditions. In some experiments (Trial 1 of Experiment 3, Experiment 5; Table 1) which had been conducted before the establishment of experimental protocols, clams retrieved from the maintenance containers were exposed to air for $2 \mathrm{~h}$ prior to cord-secretion experiments, as in Experiment 2 (see below). Note that the procedures differed slightly in some experiments; these differences are described in the appropriate sections that follow.

\section{Effects of environmental and biological factors on cord secretion}

\section{Experiment 1: Effects of air bubbling}

Clams were separated into two groups (Groups 1 and 2) at $0 \mathrm{~h}$ (Table 1). Air bubbling was applied in accordance with the experimental protocol for Group 1. For Group 2, bubbling was only applied at $2 \mathrm{~h}$ and $3 \mathrm{~h}$. Secretion of a cord was checked before and after each bubbling.

\section{Experiment 2: Effects of air exposure}

Two experimental trials (Trials 1 and 2) were conducted. Clams were retrieved from the maintenance container and then separated into two groups (Groups 1 and 2) while still submerged in filtered seawater, to avoid air exposure (Table 1). Clams in Group 1 were then exposed to air for $2 \mathrm{~h}$ at $20^{\circ} \mathrm{C}$. Clams in Group 2 (control) were returned to the container (air bubbling was resumed 10 min later when all of the clams had burrowed into the sand) and maintained for $2 \mathrm{~h}$. The clams in both groups were then retrieved and cord secretion experiments were started following the experimental protocol.

\section{Experiment 3: Effects of shell length}

Clams were separated into three size classes for two trials, Trials 1 and 2 (Table 1). Secretion experiments followed the experimental protocol in Trial 2. In Trial 1, secretion experiments were conducted at $25^{\circ} \mathrm{C}$ with pretreatment by air exposure for $2 \mathrm{~h}$ as in Experiment 2 .

\section{Experiment 4: Effects of temperature}

Clams were maintained at $20^{\circ} \mathrm{C}$ for $1 \mathrm{~d}$ after they arrived from the field. They were then separated into four groups that were maintained at temperatures of 10, 20, 25, or $30^{\circ} \mathrm{C}$ for $5 \mathrm{~d}$ (Trial 1 ; Table 1). Secretion experiments were then conducted following the experimental protocol at the temperatures at which the clams were maintained for preconditioning. Trial 2 was conducted as above except that there were no experiments at $25^{\circ} \mathrm{C}$. The experimental temperatures of 10 and $30^{\circ} \mathrm{C}$ are close to annual minimum and maximum, respectively, on Shirakawa and Oi flats (Nakamura et al. 2010); the growth of Meretrix lusoria on Oi flat was slowed at around $12^{\circ} \mathrm{C}$, but uninhibited at $30^{\circ} \mathrm{C}$ (Nakamura et al. 2009). 


\section{Experiment 5: Seasonal variation in cord secretion}

In Trials 1-3 (Table 1), clams were numbered and reared in cages on Oi tidal flat for 5-9 months in 2010 (Nakamura et al. 2010). The seasonal changes in cord secretion were monitored using the same clams repeatedly at intervals of 40-70 d: clams were retrieved from Oi flat on each occasion, examined for cord secretion, and returned to the cages within $7 \mathrm{~d}$ for subsequent experiments.

Trial 4 was conducted using clams that had not been used in previous secretion experiments. In February 2011, 120 clams (shell length, 13-22 $\mathrm{mm}$ ) were numbered, assigned to 12 groups on the basis of shell length, and were caged on Oi tidal flat as above. Twelve clams were used for each month's experiment: they were selected by choosing one clam from each group to lessen the bias in shell size distribution. Mass mortality of the caged clams in August (Nakamura et al. 2012) restricted the experiments to a period between March and July 2011. All secretion trials of Experiment 5 were conducted at $25^{\circ} \mathrm{C}$, with pretreatment by air exposure as in Experiment 2.

The dissolved oxygen concentrations of the seawater in experimental beakers were $>60 \%$ saturation at $0.8 \mathrm{~h}$ after being placed in the beaker for Experiments 1-5.

\section{Experiment 6: Cord secretion by sand-burrowing clams}

Experiments 1-5 were conducted using clams placed on hard substratum. In order to induce cord secretion under more natural conditions, Experiment 6 (Table 1) was conducted using clams burrowing in sand in a constant temperature room $\left(20^{\circ} \mathrm{C}\right)$. Clams from the sampling site were acclimated as in the experimental protocol (see above) for a few days in the dark, and then placed in two $4 \mathrm{~L}$ plastic containers containing sand (depth $3 \mathrm{~cm}$ ) and $1 \mathrm{~L}$ of oxygen-saturated filtered seawater (about 40 clams per container). After the clams burrowed into the sand (about $20 \mathrm{~min}$ after introducing them to the containers), the seawater was removed and the container was placed in the dark. On the following day (13-16 h after the removal of the seawater), $1 \mathrm{~L}$ of oxygen-saturated seawater was gently added, and the containers were placed in the dark for $1 \mathrm{~h}$ without bubbling. The room lights were then turned on, and the activity of the clams was monitored continuously for about an hour.

Clams were checked for cord secretion by pipetting about $2 \mathrm{~mL}$ water from around the siphons of the clam, and the ones that had secreted a cord were removed from the container. Following the observation of cord secretion, the room lights were turned off and the seawater was bubbled with air for 5-9 h. Seawater was again removed for cordsecretion experiments the following day. These procedures were repeated for $3 \mathrm{~d}$ for Trials 1 and 2 .

\section{Results}

Experiment 1: Effects of air bubbling

Although some clams secreted a cord in the absence of

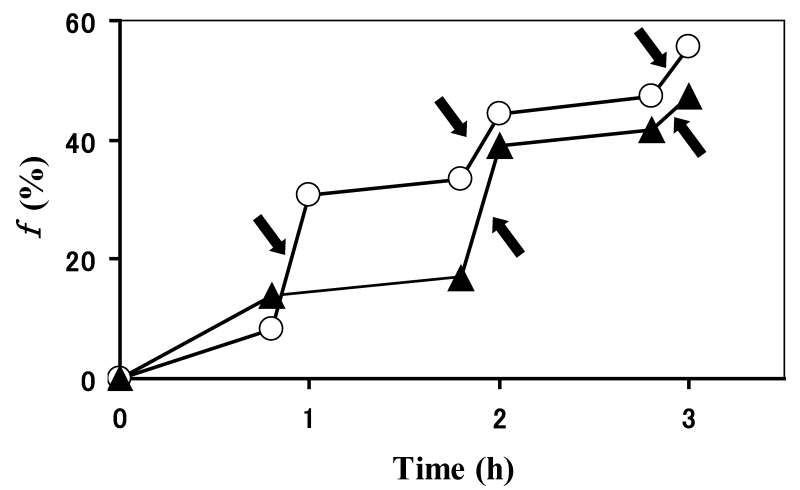

Fig. 2. Effects of air bubbling on cord secretion in Meretrix lusoria (Experiment 1). Open circles, Group 1; filled triangles, Group 2. Arrows indicate times of bubbling.

air bubbling, cord secretion was greatly enhanced by air bubbling (Fig. 2) and occurred mainly with the first of repeated stimulations by air bubbling. This pattern was consistent in other experiments except those conducted at $10^{\circ} \mathrm{C}$ (Experiment 4, see below).

\section{Experiment 2: Effects of air exposure}

The values for $f_{\mathrm{E}}$ were not significantly affected by exposing clams to air (Table 2).

\section{Experiment 3: Effects of shell length}

Clams in all size classes secreted a mucous cord (Table 2; Experiment 3). $f_{\mathrm{E}}$-values did not differ significantly among size classes in Trial land Trial 2.

\section{Experiment 4: Effects of temperature}

Although $f_{\mathrm{E}}$-values at $10^{\circ} \mathrm{C}$ were lower than those at other temperatures in Trial 1 and 2, they did not differ significantly among the temperatures tested (Table 2). Cord secretion at $20-30^{\circ} \mathrm{C}$ occurred mainly at the first stimulation by air bubbling $(1 \mathrm{~h})$, but at $10^{\circ} \mathrm{C}$ there was also considerable cord secretion at the $2-\mathrm{h}$ and 3 -h stimulations (Fig. 3).

\section{Experiment 5: Seasonal variation}

In Trials $1-3$ conducted in 2010, $f_{\mathrm{E}}$-values were high from March to May (Fig. 4a). After that, $f_{\mathrm{E}}$-values decreased to a minimum in August and increased again toward early winter. In August, $f_{\mathrm{E}}$-values for larger clams (Trials 1 and 2) were much lower than for smaller ones (Trials 3 ) and the difference among three trials were significant (see Table 1 for shell length; Chi-square test $p<0.001$ ). The seasonal pattern of cord secretion in 2011 followed the same seasonal trends as in 2010 through July (Fig. 4b). The maximum shell lengths of the clams that secreted a cord in Experiment 5 were 43 and $45 \mathrm{~mm}$ in Trials 1 and 2, respectively.

Experiment 6: Cord secretion by sand-burrowing clams

One hour after seawater was added to the containers in 
Table 2. Effects of air-exposure, shell length and water temperature on mucous cord secretion by Meretrix lusoria.

\begin{tabular}{|c|c|c|c|c|c|c|c|}
\hline Experimental treatment & Name of experiment & Trial & Treatment & $n$ & $f_{\mathrm{E}}(\%)^{\mathrm{a}}$ & $\mathrm{Chi}^{2}$ & $p^{\mathrm{b}}$ \\
\hline \multirow{2}{*}{ Exposure to air } & \multirow{2}{*}{ Exp 2} & 1 & $\begin{array}{l}\text { 2-h exposure } \\
\text { Control }\end{array}$ & $\begin{array}{l}35 \\
35\end{array}$ & $\begin{array}{l}46 \\
60\end{array}$ & 0.68 & $0.3<p<0.5$ \\
\hline & & 2 & $\begin{array}{l}\text { 2-h exposure } \\
\text { Control }\end{array}$ & $\begin{array}{l}33 \\
33\end{array}$ & $\begin{array}{l}58 \\
49\end{array}$ & 0.26 & $0.5<p<0.7$ \\
\hline \multirow{2}{*}{ Shell length } & \multirow{2}{*}{ Exp 3} & 1 & $\begin{array}{l}13-15 \mathrm{~mm} \\
20-25 \mathrm{~mm} \\
28-33 \mathrm{~mm}\end{array}$ & $\begin{array}{l}16 \\
16 \\
16\end{array}$ & $\begin{array}{l}44 \\
50 \\
50\end{array}$ & 0.09 & $p>0.9$ \\
\hline & & 2 & $\begin{array}{l}11-15 \mathrm{~mm} \\
18-21 \mathrm{~mm} \\
28-33 \mathrm{~mm}\end{array}$ & $\begin{array}{l}21 \\
29 \\
28\end{array}$ & $\begin{array}{l}81 \\
72 \\
43\end{array}$ & 3.21 & $0.1<p<0.2$ \\
\hline \multirow{2}{*}{ Water temperature } & \multirow{2}{*}{ Exp 4} & 1 & $\begin{array}{l}10^{\circ} \mathrm{C} \\
20^{\circ} \mathrm{C} \\
25^{\circ} \mathrm{C} \\
30^{\circ} \mathrm{C}\end{array}$ & $\begin{array}{l}27 \\
28 \\
27 \\
27\end{array}$ & $\begin{array}{l}33 \\
61 \\
78 \\
59\end{array}$ & 5.20 & $0.1<p<0.2$ \\
\hline & & 2 & $\begin{array}{l}10^{\circ} \mathrm{C} \\
20^{\circ} \mathrm{C} \\
30^{\circ} \mathrm{C}\end{array}$ & $\begin{array}{l}30 \\
30 \\
30\end{array}$ & $\begin{array}{l}37 \\
63 \\
77\end{array}$ & 4.22 & $0.1<p<0.2$ \\
\hline
\end{tabular}

${ }^{a}$ Cumulative proportion of cord-secreting clams at the end of each experiment.

${ }^{\mathrm{b}} p$-values were estimated based on Chi-square test.

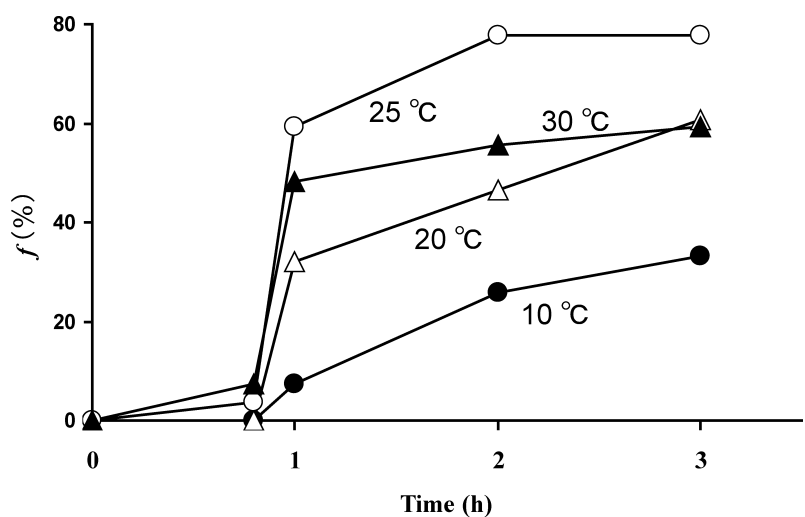

Fig. 3. Effects of temperature on cord secretion in Meretrix lusoria (Experiment 4, Trial 1). Time course of the cumulative proportion of clams secreting a cord $(f)$.

Trials 1and 2, about $20-40 \%$ of the clams crawled out of the sand in the dark. At this point, the dissolved oxygen concentration was still approximately $60 \%$ of saturation. Immediately after turning on the light, most clams started to burrow back into the sand. However, some clams extended their foot and siphons to a great degree, crawled on the surface of the sand (Fig. 1a), and secreted a mucous cord (Fig. 1b). In most cases cord secretion occurred within 10 min after turning on the light. In total, 9 of 80 and 2 of 85 clams secreted a cord over the 3 -d experiment (a)

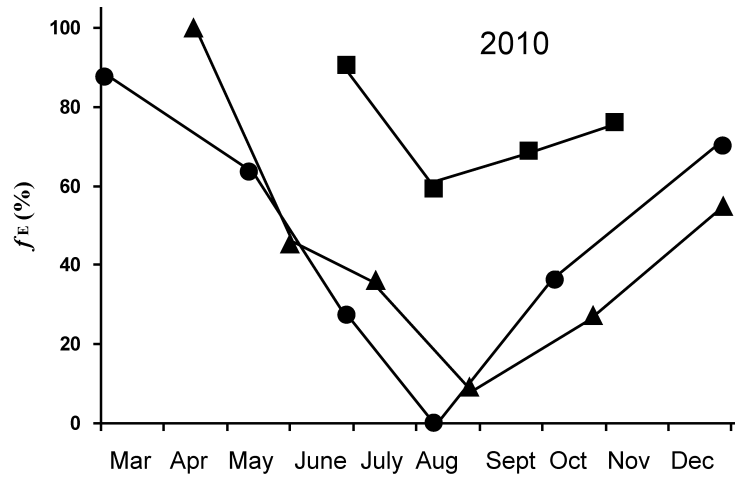

(b)

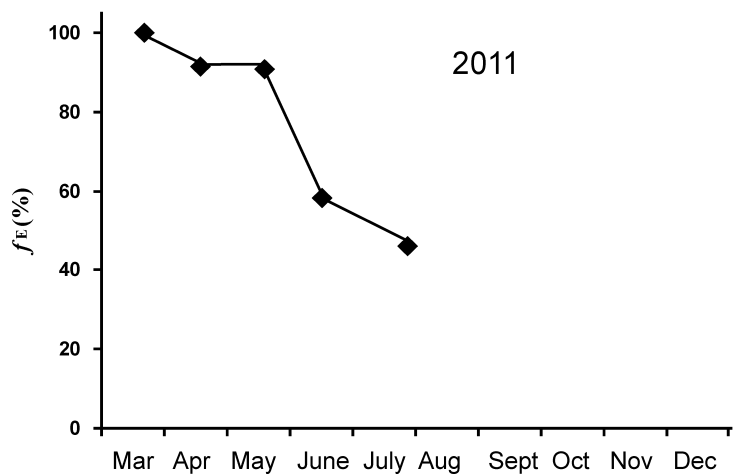

Fig. 4. Seasonal changes in $f_{\mathrm{E}}$-values (cumulative proportion of Meretrix lusoria clams secreting a cord at 3 h) in 2010 (a) and 2011 (b). Filled circles, triangles, squares and diamonds are for Experiment 5 Trials 1, 2, 3 and 4, respectively. 
in Trials 1 and 2, respectively.

\section{Discussion}

A mucous cord was secreted by Meretrix lusoria over a wide range of shell sizes (11-45 $\mathrm{mm}$ in shell length) and over a wide temperature range $\left(10-30^{\circ} \mathrm{C}\right)$ with stimulation by air bubbling. Cord secretion showed seasonality, with the proportion of clams secreting a cord reaching a minimum in summer.

In Trial 1 of Experiment 3 and in Experiment 5, experimental conditions differed from the experimental protocol; clams were exposed to air for $2 \mathrm{~h}$ and then secretion experiments were conducted at $25^{\circ} \mathrm{C}$. However, as air exposure just before secretion experiments and experimental temperatures between 20 and $25^{\circ} \mathrm{C}$ did not affect cord secretion, it is reasonable to treat the results of these experiments the same as those following the subsequently established experimental protocol.

As the time required for the recovery of cord secretion ability is unknown, the seasonal trends of cord secretion in 2010 might have been biased from using same clams in successive secretion experiments. To avoid this potential bias, experiments in 2011 were conducted using clams that had not been used in previous secretion experiments. Although the period of experiment was restricted from March to July 2011, the seasonal trend during this period was similar to that in 2010. Thus, any bias due to the use of clams that had already secreted a cord was considered minor.

\section{Effects of air bubbling}

Air bubbling enhanced cord secretion in Meretrix lusoria. As air bubbling introduces oxygen into seawater, liberation of the clams from hypoxic condition might have induced cord secretion. However, dissolved oxygen concentrations at $t$ of $0.8 \mathrm{~h}$ after being placed in the beaker (before air bubbling) were $>60 \%$ of saturation. This indicates that the above scenario is not realistic, and that cord-secretion was probably enhanced by water movement caused by air bubbling. The enhancing influence of water currents on mucous material secretion has also been observed in other bivalve and gastropod species (e.g. Prezant \& Chalermwat 1984, Sorlin 1988, Martel \& Diefenbach 1993).

If clams on tidal flats crawl out of the sand for some reason (e.g. crawling out during darkness; see results in Experiment 6), it is anticipated that water movement induced by tides and/or wind may stimulate cord secretion. This scenario is consistent with the observations that drifting of Meretrix clams on tidal flats off the Korean Peninsula were enhanced during spring ebb tides or on windy days (Uchida 1941). The relationship between water current and cord-secretion of $M$. lusoria requires a follow-up quantitative analysis.

\section{Relationship to shell length}

A substantial proportion of Meretrix lusoria in all size classes secreted a cord in Experiment $3\left(f_{\mathrm{E}}>43 \%\right)$. In addition, clams with shell lengths of $45 \mathrm{~mm}$ (Experiment 5), and those of shell length of 21-28 mm that crawled out of the sand (Experiment 6), secreted a cord. As M. lusoria matures at a shell length of 17-20 mm (Nakamura et al. 2010), these observations indicate that both juvenile and adult $M$. lusoria have the potential for cord secretion. This contrasts with other molluscan species, in which the secretion of mucous materials has been observed mainly in juveniles (Sigurdsson et al. 1976) or in adults $<20 \mathrm{~mm}$ in shell length (Sorlin 1988, Martel \& Diefenbach 1993). Thus, M. lusoria is unique in that large adults $(>20 \mathrm{~mm})$ have the ability to secrete mucous material.

One might consider that cords secreted by large clams $(>20 \mathrm{~mm}$ ) are not sufficient to enable clams to drift on a tidal flat. However, some clams (up to $25 \mathrm{~mm}$ in shell length) that secreted a cord during air bubbling in Experiments 1-5 'lifted off' and floated in the seawater by the action of bubbles and water movement (Nakamura personal observation). In addition, Uchida (1941) observed that $M$. meretrix (probably $M$. lusoria) of shell length $3-5 \mathrm{~cm}$ trailed a cord into the tidal current and drifted on a tidal flat off the southern Korean Peninsula. Thus, it is apparent that cords secreted by M. lusoria with a shell length $<5 \mathrm{~cm}$ can be used for drifting.

The Meretrix meretrix (probably M. petechialis) collected in clam traps on a tidal flat off the northwestern Korean Peninsula (Uchida 1941) were $20-60 \mathrm{~mm}$ in shell length, although the author did not indicate the mesh size of the collecting net. The M. lusoria stranded on obstacles, probably through drift, on Shirakawa flat were $20-49 \mathrm{~mm}$ (Takahi \& Henmi 2011). However, M. lusoria of shell length $<20 \mathrm{~mm}$ (Experiment 3 ) and those of shell length of 8 and $13 \mathrm{~mm}$ (Experiment 6) secreted a cord. This discrepancy should be examined in the future by conducting clam-trap experiments in the field using a collecting net with a mesh size of $<10 \mathrm{~mm}$.

\section{Effects of temperature and seasons}

Meretrix lusoria had the potential to secrete a cord at all temperatures examined $\left(10-30^{\circ} \mathrm{C}\right)$ with $f_{\mathrm{E}}$-values $>33 \%$. In addition, experiments investigating seasonal variations of cord secretion indicate that $f_{\mathrm{E}}$-values were higher in spring and decreased to a minimum in August. These results are consistent with the observations that the number of clams stranded on obstacles on Shirakawa flat peaked in spring and decreased drastically in August (when water temperature was approximately $30^{\circ} \mathrm{C}$ ), and that some M. lusoria drifted in January and February when the water temperature decreased to $12^{\circ} \mathrm{C}$ (Takahi \& Henmi 2011).

On tidal flats off the Korean Peninsula, Meretrix clams were reported to drift mainly during summer and early fall (Uchida 1941). This appears inconsistent with the results of the present study, which found minimum $f_{\mathrm{E}}$-values in August (Fig. 4). However, note that (1) the time of minimum $f_{\mathrm{E}}$-values coincides with the period just before 
spawning for M. lusoria (Nakamura et al. 2010), (2) $f_{\mathrm{E}^{-}}$ values rebounded a few months later, and (3) the spawning of ' $M$. lusoria' (probably M. petechialis) on tidal flats off western Korea starts in June (Chung 2007), two months earlier than M. lusoria in Japan. Thus, this apparent inconsistency could be explained if there is a link between the cycle of sexual reproduction in Meretrix clams and the trend in the timing of cord secretion.

\section{Cord secretion by sand-burrowing clams}

Cord secretion was induced by mild stimulation (changes from emersion to submergence and in light conditions), suggesting that clams in the field secrete the cord without being in adverse conditions. If so, the question then arises as to why a mucous cord is secreted.

Shirakawa flat contained a hot spot of early juvenile M. lusoria (shell length $<4 \mathrm{~mm}$ ). These juveniles were very abundant at stations close to the main stream of the Shirakawa River, at the level of MLWN, as confirmed by monitoring of benthic species at 99 stations during 2004, 2005, and 2007 (Tamaki \& Takahara, unpublished data). In addition, clams with shell length $>10 \mathrm{~mm}$ were distributed widely on the tidal flat, probably facilitated by drifting of the clams with the aid of mucous cords. If this is a general pattern, then the following is presented as a possible ecological role of mucous cord drifting: an aggregation close to a river has a potential risk of large-scale mortality of the population through the thick accumulation of muddy sediments that occurs sporadically as a result of heavy precipitation (once every several years in the Shirakawa River). Thus, drifting of M. lusoria over a wider area would serve an ecological role in preventing the total loss of the aggregated population.

It should also be noted that the emersion period in Experiment $6(13-16 \mathrm{~h})$ was much longer than that on natural tidal flat and this potential stress could have induced cord secretion. Further experiments are in progress to induce cord-secretion in response to systematically varying exposure periods and light conditions. Preliminary results indicate that cord secretion occurs following an emersion period of $6 \mathrm{~h}$, suggesting support for the above scenario for the role of cord secretion.

\section{Acknowledgements}

The author thanks A. Tamaki for providing unpublished data and valuable comments in this study.

\section{References}

Bayne BL (1964) Primary and secondary settlement in Mytilus edulis L. (Mollusca). J Anim Ecol 33: 513-523.

Beukema JJ, Vlas J de (1989) Tidal-current transport of threaddrifting postlarval juveniles of the bivalve Macoma balthica from the Wadden Sea to the North Sea. Mar Ecol Prog Ser 52: 193-200.
Chung E-Y (2007) Oogenesis and sexual maturation in Meretrix lusoria (Roeding 1978) (Bivalvia: Veneridae) in western Korea. J Shellfish Res 26: 71-80.

Hamada S, Ino T (1954) Studies on the movement of the Japanese hard clam, Meretrix meretrix lusoria (Roeding) I. Histological studies on the mucous gland in relation to locomotion. Bull Jap Soc Sci Fish 20: 1-8 (in Japanese with English abstract).

Hiddink JG, Wolff WJ (2002) Changes in distribution and decrease in numbers during migration of the bivalve Macoma balthica. Mar Ecol Prog Ser 233: 117-130.

Higano J (2004) Influence of environmental changes in tidal flats on the filtration and respiration of bivalve mollusks. Bull Fish Res Agency Suppl 1: 33-40.

Kishinouye K (1913) On a peculiar mode of locomotion of a clam Meretrix meretrix L. Zoologischer Anzeiger bd 41: 445-446.

Lane DJW, Beaumont AR, Hunter JR (1985) Byssus drifting and the drifting of the young post-larval mussel Mytilus edulis. Mar Biol 84: 301-308.

Martel A, Diefenbach T (1993) Effects of body size, water current and microhabitat on mucous-thread drifting in post-metamorphic gastropods Lacuna spp. Mar Ecol Prog Ser 99: 215220.

Nakamura Y, Kanaya G, Koizumi T, Maki H (2012) Survival of clams on Oi tidal flat in Tokyo Bay in relation to environmental variables including dissolved oxygen and sulfides. J Jpn Soc Water Environ 35: 127-134.

Nakamura Y, Koizumi T, Ichimura Y, Kohata K (2009) Survival and growth of the clam Meretrix lusoria on a hypoxia-prone tidal flat: comparisons with other clam species. J Jpn Soc Water Environ 32: 549-555 (in Japanese with English abstract).

Nakamura Y, Nakano T, Yurimoto T, Maeno Y, Koizumi T, Tamaki A (2010) Reproductive cycle of the venerid clam Meretrix lusoria in Ariake Sound and Tokyo Bay, Japan. Fish Sci 76: 931-941.

Prezant RS, Chalermwat K (1984) Flotation of the bivalve Corbicula fluminea as a means of dispersal. Science 225: 14911493.

Sigurdsson JB, Titman CW, Davis PA (1976) The dispersal of young post-larval bivalve molluses by byssus threads. Nature 262: 386-387.

Sorlin T (1988) Floating behaviour in the tellinid bivalve Macoma balthica (L.). Oecologia 77: 273-277.

Takahi S, Henmi Y (2011) Migration by mucous cord in the hard clam Meretrix lusoria. Jpn J Benthology 65: 76-81 (in Japanese with English abstract).

Tamaki A, Nakaoka A, Maekawa H, Yamada F (2008) Spatial partitioning between species of the phytoplankton-feeding guild on an estuarine intertidal sand flat and its implication on habitat carrying capacity. Est Coast Shelf Sci 78: 727-738.

Trii H, Sato S, Hamaguchi M, Henmi Y, Yamashita H (2010) The comparison of shell morphology and genetic relationship between Meretrix lusoria and M. petechialis in Japan and Korea. Plankton Benthos Res 5: 231-241.

Uchida K (1941) Migration of Meretrix meretrix on Korean tidal flat. Suisanngakkaihou 8: 218-230 (in Japanese). 